\title{
Women's Reports of Dense Breast Notification Following Mammography: Findings from the 2015 National Health Interview Survey
}

\author{
Thomas B. Richards, $M D^{7}{ }^{1}$, Sabitha Dasari, MBBS, MPH${ }^{2}$, Susan A. Sabatino, MD, MPH', \\ Jin Qin, $S C D^{7}$, Jacqueline W. Miller, $M D^{7}$, and Mary C. White, $S c D^{7}$ \\ 'Division of Cancer Prevention and Control, National Center for Chronic Disease Prevention and Health Promotion, Centers for Disease Control and \\ Prevention, Atlanta, GA, USA; ${ }^{2}$ Cyberdata Technologies, Atlanta, GA, USA.
}

J Gen Intern Med 35(7):2207-9

DOI: $10.1007 / \mathrm{s} 11606-019-05619-\mathrm{x}$

(c) Society of General Internal Medicine (This is a U.S. government work and not under copyright protection in the U.S.; foreign copyright protection may apply) 2020

\section{INTRODUCTION}

Increased breast density (defined as radiopaque areas on a mammogram from heterogeneously or extremely dense breast tissue) is identified in about half of women undergoing digital mammography screening exams. ${ }^{1}$ Increased breast density is a risk factor for breast cancer and can mask breast cancer. ${ }^{2}$ From 2009 to 2019,36 states enacted laws to require information on increased breast density in mammography reports. ${ }^{3}$ The National Health Interview Survey (NHIS) ${ }^{4}$ included a question about dense breast notification only in 2015 .

\section{METHODS}

We used the 2015 NHIS Cancer Control Supplement ${ }^{4}$ publicuse data set to estimate the prevalence of breast density notification and additional tests following mammography. The NHIS is a cross-sectional, in-person survey of a nationally representative sample of the civilian, noninstitutionalized U.S. population, with a multistage cluster sample design. The final sample adult response rate in 2015 was $55.2 \%$. Our study included 5701 women aged 35-74 years who had no prior breast cancer diagnosis, who reported a mammogram as part of a routine exam and not because of a problem within the past 2 years, and who were not missing information about breast density and additional testing.

We identified dense breast notification after a woman's most recent mammogram with the question: "Were you informed that your mammogram showed that you have dense breast tissue?" Additional tests were identified with: "After your MOST RECENT mammogram, were you advised to have more tests?" and, if yes, "What tests did you actually

Received September 7, 2019

Revised October 30, 2019

Accepted December 12, 2019

Published online January 6, 2020 have?" (none, ultrasound, breast magnetic resonance imaging, additional mammogram(s), biopsy, other).

We used SAS-callable SUDAAN version 11.0 software and NHIS-provided final weights for adult sampling probabilities and nonresponse. We used logistic regression to calculate modeladjusted risk ratios derived from predicted marginals for whether a woman was informed about dense breast tissue by factors such as health status, sociodemographics, and census region.

\section{RESULTS}

Overall, $24.9 \%$ of our sample reported they were informed that their mammogram showed dense breast tissue (Table 1). Model-adjusted risk ratios for notification were lower than the reference group for women who were aged $\geq 55$ years, were black or Hispanic, had not had a mammogram in the past year, were born outside the USA, were not a college graduate, or had income $<250 \%$ of the federal poverty threshold (Table 1). Risk ratios were higher than the reference group for women in the Northeast and those with a first-degree family history of breast cancer.

Of the group of women informed about dense breast tissue, $26.2 \%$ reported additional tests following mammography, with ultrasound $(14.6 \%)$ being the most common additional test (data about additional tests is not shown in table). Of women not informed about dense breast tissue, only 3.4\% reported additional tests.

\section{DISCUSSION}

One in four women in 2015 in all states reported being notified of dense breast tissue following a recent mammogram. This proportion is half of what would be expected if notifications had been required nationwide in 2015. ${ }^{1}$ Women with less education, lower income, black or Hispanic heritage, or age group 55-74 years and those who were immigrants were less likely to report dense breast notification.

Ultrasound was the additional test most commonly reported following mammography by women with dense breast notification. Whether the ultrasound was for increased breast 
Table 1 Prevalence and Model-Adjusted Risk Ratios of Notification That a Recent Mammogram Showed Dense Breast Tissue, Among Women Aged 35-74 Years, National Health Interview Survey, 2015

\begin{tabular}{|c|c|c|c|c|c|}
\hline Characteristics & $N$ & $n$ & $\begin{array}{l}\text { Prevalence of notification } \\
(95 \% \mathrm{CI})\end{array}$ & $\begin{array}{l}\text { Model-adjusted risk ratios } \\
(95 \% \text { CI })\end{array}$ & $p$ value* \\
\hline Total & 5701 & 1311 & $24.9(23.4-26.5)$ & - & - \\
\hline \multicolumn{6}{|l|}{ Age } \\
\hline $35-44$ years & 699 & 177 & $28.3(24.3-32.6)$ & $1.13(0.95-1.34)$ & 0.18 \\
\hline $45-54$ years & 1679 & 389 & $26.6(23.9-29.5)$ & 1.00 (Reference) & - \\
\hline $55-64$ years & 1834 & 435 & $23.8(21.2-26.5)$ & $0.86(0.75-1.00)$ & 0.048 \\
\hline $65-74$ years & 1489 & 310 & $22.1(19.6-24.8)$ & $0.82(0.70-0.97)$ & 0.018 \\
\hline \multicolumn{6}{|l|}{ Race/ethnicity } \\
\hline White, non-Hispanic & 3633 & 1012 & $29.0(27.1-31.0)$ & 1.00 (Reference) & - \\
\hline Black, non-Hispanic & 917 & 134 & $16.4(13.1-20.3)$ & $0.67(0.53-0.84)$ & $<0.001$ \\
\hline Other, non-Hispanic & 329 & 62 & $21.0(16.2-26.6)$ & $0.86(0.65-1.13)$ & 0.25 \\
\hline Hispanic & 822 & 103 & $13.4(10.5-16.9)$ & $0.69(0.53-0.91)$ & 0.002 \\
\hline \multicolumn{6}{|l|}{ Most recent mammogram } \\
\hline 1 year ago or less & 4386 & 1053 & $26.2(24.4-28.1)$ & 1.00 (Reference) & - \\
\hline$>1$ year but $<2$ years & 1315 & 258 & $20.7(18.0-23.7)$ & $0.80(0.69-0.93)$ & 0.003 \\
\hline \multicolumn{6}{|l|}{ Region } \\
\hline Northeast & 1100 & 306 & $30.7(27.1-34.5)$ & $1.18(1.01-1.39)$ & 0.045 \\
\hline Midwest & 1138 & 252 & $22.6(19.5-26.1)$ & $0.84(0.70-1.00)$ & 0.051 \\
\hline West & 1463 & 343 & $23.8(20.9-27.1)$ & $1.00(0.85-1.17)$ & 0.98 \\
\hline South & 2000 & 410 & $24.0(21.4-26.8)$ & 1.00 (Reference) & - \\
\hline \multicolumn{6}{|l|}{ Born in the USA } \\
\hline Yes & 4714 & 1174 & $27.0(25.2-28.8)$ & 1.00 (Reference) & - \\
\hline No & 915 & 129 & $14.8(12.2-17.8)$ & $0.68(0.53-0.86)$ & $<0.001$ \\
\hline Unknown/missing & 72 & 8 & & - & - \\
\hline \multicolumn{6}{|l|}{ Family history of breast cancer ${ }^{\ddagger}$} \\
\hline Yes & 792 & 243 & $33.6(29.4-38.1)$ & $1.35(1.17-1.57)$ & $<0.001$ \\
\hline No & 4436 & 943 & $23.2(21.6-25.0)$ & 1.00 (Reference) & - \\
\hline Unknown/missing & 473 & 125 & $26.8(21.6-32.7)$ & - & - \\
\hline \multicolumn{6}{|l|}{ Education } \\
\hline$<$ High school graduate & 1891 & 291 & $17.3(15.4-19.4)$ & $0.70(0.60-0.81)$ & $<0.0001$ \\
\hline Some college & 1839 & 414 & $23.0(20.5-25.8)$ & $0.80(0.69-0.93)$ & 0.003 \\
\hline College graduate & 1955 & 604 & $33.0(30.1-36.1)$ & 1.00 (Reference) & - \\
\hline Unknown/missing & 16 & 2 & & - & - \\
\hline \multicolumn{6}{|c|}{ Family income (percent of federal poverty threshold) } \\
\hline$<138 \%$ & 1116 & 156 & $14.9(12.0-18.4)$ & $0.72(0.57-0.92)$ & 0.005 \\
\hline$\geq 138<250 \%$ & 1034 & 169 & $15.9(13.1-19.2)$ & $0.70(0.56-0.86)$ & $<0.001$ \\
\hline$\geq 250<400 \%$ & 1154 & 280 & $25.7(22.6-29.2)$ & $0.99(0.85-1.16)$ & 0.90 \\
\hline$\geq 400 \%$ & 2397 & 706 & $30.6(28.0-33.3)$ & 1.00 (Reference) & - \\
\hline \multicolumn{6}{|l|}{ Body mass index $(\mathrm{BMI})^{\S}$} \\
\hline$<18.5$ (underweight) & 70 & 15 & $\dagger$ & - & - \\
\hline$>18.5<25$ (healthy weight) & 1786 & 467 & $27.7(25.0-30.6)$ & 1.00 (Reference) & - \\
\hline$\geq 25-<30$ (overweight) & 1672 & 400 & $26.8(24.1-29.6)$ & $1.06(0.92-1.23)$ & 0.39 \\
\hline$\geq 30$ (obese) & 1925 & 373 & $20.8(18.1-23.8)$ & $0.91(0.77-1.09)$ & 0.30 \\
\hline Ūnknown & 248 & 56 & $23.6(16.8-32.2)$ & - & - \\
\hline \multicolumn{6}{|l|}{ Health insurance } \\
\hline Not covered & 231 & 39 & $17.7(11.8-25.6)$ & $1.03(0.73-1.46)$ & 0.88 \\
\hline Covered & 5455 & 1269 & $25.2(23.6-26.8)$ & 1.00 (Reference) & - \\
\hline Unknown/missing & 15 & 3 & & - & - \\
\hline
\end{tabular}

$C I$, confidence interval; $N$, total number of women in the row category; $n$, number of women who reported notification of dense breast tissue $N$ and $n$ are unweighted numbers. Prevalence estimates are weighted. Prevalence estimates are row percentages. Model-adjusted risk ratios are derived from predicted marginals and adjusted for all variables in the table

* $p$ values are for the model-adjusted risk ratios, comparing the row in a category with the reference group for that category

tEstimate suppressed because $n<30$ or relative standard error is $>30 \%$

$\$$ Family history of breast cancer in a first-degree relative (mother, sister, or daughter)

${ }^{\xi}$ BMI calculated using the National Health Interview Survey recode variable

density or another mammographic finding is unknown. Survey responses were self-reported and not validated by medical records. Another limitation is that the NHIS public-use data withholds state geographic identifiers needed to analyze associations with state laws on dense breast notification. ${ }^{3}$

Looking towards the future, primary care providers are likely to receive mammogram reports with information about increased breast density. ${ }^{5}$ Implications for clinicians, patient education, and research include how to best communicate information about dense breast tissue to women, and what are the appropriate additional tests. ${ }^{5}$ In 2016, the US Preventive Services Task Force concluded that scientific evidence was insufficient to assess the balance of benefits and harms of adjunctive screening in women with dense breast tissue on an otherwise negative screening mammogram. ${ }^{2}$ Examples of research topics that might be beneficial to clinical practice include the use of breast cancer risk calculators ${ }^{1}$ as part of discussions about increased breast density, and studies to identify effective adjunctive screening tests. ${ }^{6}$

Corresponding Author: Thomas B. Richards, MD; Division of Cancer Prevention and Control National Center for Chronic Disease Prevention and Health Promotion, Centers for Disease Control and Prevention, 4770 Buford Highway NE, Atlanta, GA MS S107-4, USA (e-mail: TRichards@cdc.gov). 
Compliance with Ethical Standards: The National Center for Health Statistics (NCHS) Research Ethics Review Board and the Office of Management and Budget (OMB) approved the 2015 National Health Interview Survey data collection.

Conflict of Interest: The authors declare that they do not have a conflict of interest.

Disclaimer: The findings and conclusions in this report are those of the authors and do not necessarily represent the official position of the Centers for Disease Control and Prevention, the National Cancer Institute, or the National Institutes of Health.

Publisher's Note: Springer Nature remains neutral with regard to jurisdictional claims in published maps and institutional affiliations.

\section{REFERENCES}

1. Kerlikowske K, Sprague BL, Tosteson ANA, Wernli KJ, Rauscher GH, Johnson D, et al. Strategies to identify women at high risk of advanced breast cancer during routine screening for discussion of supplemental imaging. JAMA Intern Med. 2019; 179(9):1230-1239. https://doi.org/10. 1001/jamainternmed.2019.1758.
2. U.S. Preventive Services Task Force. Breast cancer: screening. Final recommendation statement. 2016. Accessed at https://www. uspreventiveservicestaskforce.org/ on 30 October 2019.

3. Are You Dense Advocacy, Inc. State Density Reporting Efforts - because your life matters. 36 State Density Reporting Laws. Accessed at https:// www.areyoudenseadvocacy.org/dense on 30 October 2019.

4. National Center for Health Statistics. National Health Interview Survey. Questionnaires, Datasets, and Related Documentation. Accessed at https://www.cdc.gov/nchs/nhis/data-questionnaires-documentation. htm on 30 October 2019.

5. Keating NL, Pace LE. New federal requirements to inform patients about breast density: will they help patients? JAMA. 2019;321(23):2275-2276. https://doi.org/10.1001/jama.2019.5919.

6. Lee JM, Arao RF, Sprague BL, et al. Performance of screening ultrasonography as an adjunct to screening mammography in women across the spectrum of breast cancer risk. JAMA Intern Med. 2019;179(5):658-667. https://doi.org/10.1001/jamainternmed.2018.8372

Publisher's Note Springer Nature remains neutral with regard to jurisdictional claims in published maps and institutional affiliations. 